http://dx.doi.org/10.11646/phytotaxa.167.2.7

\title{
Buxus holttumiana of Peninsular Malaysia and Thailand is a variety of $B$. cochinchinensis (Buxaceae)
}

\author{
AVELINAH JULIUS \\ Forest Research Institute Malaysia, 52109 Kepong, Selangor, Malaysia, e-mail: avelinah@frim.gov.my
}

The Flora of Peninsular Malaysia project was initiated in 2005 (Kiew \& Rafidah 2007, Saw \& Chung 2007), and aims to document the entire flora of the region formerly known as Malaya or Malay Peninsula. As part of this project, the present author is revising the Buxaceae for the Flora, represented in Peninsular Malaysia by the single genus Buxus Linnaeus (1753: 983). The genus was last revised by Hatusima in 1942, and in his revision, Hatusima recognized three species in Peninsular Malaysia [viz. Buxus holttumiana Hatusima (1942: 270), B. malayana Ridley (1926: 475) and B. rupicola Ridley (1911: 166)]. All three taxa are confined to limestone forests at 20-450 $\mathrm{m}$ above sea level, and Hatusima (1942) considered all species as endemic to Peninsular Malaysia. In his revision, however, Hatusima described B. holttumiana from a single collection gathered in 1938 from Kaki Bukit, Perlis (Kiah SFN 35239, see Figure 1A \& B) and considered the thicker, shining leaves with fewer veins, the longer, erect (not strongly recurved and divaricating) styles as diagnostic characters for this species. Hatusima (1942), however, stated that he did not compare his new taxon with material of B. cochinchinensis Pierre ex Gagnepain (1921: 481), and his description of the latter was more or less a verbatim transcription of Gagnepain's (Gagnepain 1921).

Buxus cochinchinensis is a common species found throughout China, Vietnam and Thailand. It is a shrub with smaller leaves measuring $6.5-12.5(-16.5) \times 2.3-6.5 \mathrm{~cm}$, and the secondary veins up to 15 pairs are well-spaced, curving upwards and joining towards the margin (brochidodromous). The capsule is subglobose $(7-9 \times 7-10 \mathrm{~mm})$ with the style erect and slightly curved at apex. However, collections with larger leaves than normally found in $B$. cochinchinensis, have been collected from southern Thailand (Rabil 148, see Figure 1C), most recently in 2003 (Middleton et al. 2136, see Figure 1D).

During the preparation of the treatment of the Buxaceae for the Flora of Peninsular Malaysia, it was found that the material of Buxus holttumiana is similar to the large-leaved collections from southern Thailand. The species is therefore conspecific with Buxus cochinchinensis.

Buxus cochinchinensis var. holttumiana (Hatus.) Julius, comb. et stat. nov. (Fig. 1)

Buxus holttumiana Hatusima (1942: 27, fig. 1). Type:-MALAYSIA. Peninsular Malaysia: Perlis, Titi Tinggi, Kaki Bukit, 11 April 1938 (fl, fr), M.S. Kiah SFN 35239 (holotype SING!; isotypes K!, KEP!).

Shrub, 40-60 cm tall, glabrous. Bark pale grey, fissured. Twigs of new growth quadrangular, becoming subterete with obscure angles with age. Leaves simple, opposite-decussate; petioles 3-4 $\mathrm{mm}$ long; blades ovate-lanceolate, rarely ovate-elliptic or broadly lanceolate, $12-18.5 \times 4.5-7 \mathrm{~cm}$, chartaceous to subcoriaceous, base cuneate, margin entire, revolute, apex acuminate to subcaudate, acumen 1.5-3 cm long, dull beneath, glossy above; midrib raised beneath, impressed above; secondary veins 15-19 pairs, well-spaced, curving upwards and brochidodromous; tertiary veins obscure beneath, prominent above. Inflorescences axillary, racemose; axes glabrous, 5-8 mm long; bracts 4-5, subulate, 1-1.5 mm long, glabrous on both sides. Male flowers: up to 10, pedicels 2-3 mm long, glabrous; tepals elliptic-oblong, ca. $3 \times 1-1.5 \mathrm{~mm}$, concave, keeled, glabrous except dense, long white hairs on apex, cream to pinkish orange; stamens 4, filaments ca. $1.5 \mathrm{~mm}$ long, anthers reflexed, cream; pistilode orange-pink. Female flower (in bud): tepals 6, ovate, $1.2-1.5 \times 1 \mathrm{~mm}$, margin ciliolate, apex acute, with dense, white hairs inside; styles ca. $1 \mathrm{~mm}$ long, broad at base; stigma whitish, oblanceolate, 3-4 mm long, narrowed at base, apex recurved; ovary ovoid-triangular, red-brown when dried. Capsules (young) subglobose, 10-12 $\times 3-8 \mathrm{~mm}$, green, style elongated to $10 \mathrm{~mm}$ long and spreading distinctly. Seeds trigono-ellipsoid, 7-8 mm long, $2-3 \mathrm{~mm}$ in diameter. 


\section{References}

Baillon, H.E. (1859) Monographie des Buxacées et des Stylocérées. Masson, Paris, 89 pp.

Chua, L.S.L. (2010) Conservation. In: Kiew, R., Chung, R.C.K., Saw, L.G. \& Soepadmo, E. (eds) Flora of Peninsular Malaysia series 2, 1. Forest Research Institute Malaysia, Kepong, pp. 47-54.

Gagnepain, F. (1921) Euphorbiaceae nouvelles (Buxus et Sarcococca). Bulletin de la Société Botanique de France 68: $481-483$.

Hatusima, S. (1942) A revision of the Asiatic Buxus. Journal of the Department of Agriculture, Kyusu Imperial University 6(6): 261-354.

IUCN (2001) Red list categories and criteria version 3.1. IUCN Species Survival Commission, IUCN, Gland, Switzerland \& Cambridge, UK. Available from: http://www.iucnredlist.org/technical-documents/categories-and-criteria/2001-categoriescriteria (accessed 9 April 2013)

Kiew, R. \& Rafidah, A.R. (2007) The Flora of Peninsular Malaysia Project. Conservation Malaysia 5: 1-4.

Linnaeus, C. (1753) Species Plantarum. L. Salvius, Stockholm, 1200 pp.

Ridley, H.N. (1911) An account of botanical expeditions to lower Siam. Journal of the Straits Branch of the Royal Asiatic Society 59: 27-234.

Ridley, H.N. (1926) Additions to the Flora of Malaya. Bulletin of Miscellaneous Information Kew 1926: 469-479.

Saw, L.G. \& Chung, R.C.K. (2007) Towards the Flora of Malaysia. In: Chua, L.S.L., Kirton, L.G. \& Saw, L.G. (eds.) Proceeding of the seminar and workshop status of biological diversity in Malaysia and threat assessment of plant species in Malaysia, 28-30 June 2005. Forest Research Institute Malaysia, Kepong, pp. 211-227. 